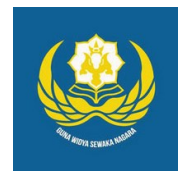

Jurnal Analogi Hukum

Journal Homepage: https://ejournal.warmadewa.ac.id/index.php/analogihukum

\title{
Hak Eksekutorial Lembaga Perkreditan Desa Terhadap Benda Jaminan Hak Tanggungan yang Berkedudukan di Luar Wilayah Desa Adat
}

\author{
I Putu Yoga Eka Putra Gunawan*, I Nyoman Putu Budiartha dan Ni Made Puspasutari Ujianti \\ Universitas Warmadewa, Denpasar-Bali, Indonesia \\ *yogaekaputra98@yahoo.co.id
}

\begin{abstract}
How To Cite:
Gunawan, I, P, Y, E, P., Budiartha, I, N, P., Ujianti, N, M, P. (2021). Hak Eksekutorial Lembaga Perkreditan Desa Terhadap Benda Jaminan Hak Tanggungan yang Berkedudukan di Luar Wilayah Desa Adat. Jurnal Analogi Hukum. 3 (2). 183-187. Doi: https:// doi.org/10.22225/ah.3.2.2021.183-187
\end{abstract}

\begin{abstract}
LPD is a financial institution belonging to the Traditional Village which is domiciled in the authority of the Traditional Village. Furthermore, the following issues will be discussed: (1)How is the Regulation of Village Credit Institutions as Traditional Village Financial Institutions in Bali, (2)How is the Existence of Village Credit Institutions Against Mortgage Guaranteed Objects Located Outside the Traditional Village. The research method is normative and the type of approach This problem consists of a statutory approach and a conceptual approach. The sources of legal materials used are primary legal materials in the form of laws and regulations. Legal Materials Collection Techniques through documentation study techniques and literature studies. peeling of lawful Materials through depiction, interpretation and argument techniques. A conclusion thesis is valid according to the rules of Article 5 paragraph (1) Governor Regulation No. 44 of 2017 and Law Number 4 of 1996 provide for validity of the LPD's execution which gives the authority to the first party to keep an auction so that it carries the purpose of pawn on its own strength.
\end{abstract}

Keywords: executional rights; mortgage right; village credit institutions

\begin{abstract}
Abstrak - LPD adalah suatu badan perniagaan yang dipunyai oleh Desa Adat yang bertempat pada daerah wewidangan Desa Adat. Selanjutnya akan dibahas permasalahan: (1) Bagaimana Pengaturan Lembaga Perkreditan Desa Sebagai Lembaga Keuangan Desa Adat di Bali, (2) Bagaimana Eksistensi Lembaga Perkreditan Desa Terhadap Benda Jaminan Hak Tanggungan Yang Berkedudukan di Luar Desa Adat. Metode penelitian adalah normatif dan Jenis pendekatan Masalah ini terdiri dari pendekatan perundang-undangan dan pendekatan konseptual. Sumber Bahan Hukum yang digunakan adalah Bahan Hukum Primer berupa peraturan perundang-undangan dan Bahan Hukum Sekunder meliputi bentuk tulisan ilmiah tentang hukum. Teknik Pengumpulan Bahan hukum melalui teknik studi dokumentasi dan studi kepustakaan. Analisis Bahan Hukum melalui teknik deskripsi, interpretasi dan argumentasi. Dan kesimpulan dari skripsi adalah sah sesuai aturan Pasal 5 ayat (1) Pergub No. 44/2017 serta pada UU No. 4/1996 memberikan keabsahan eksekutorial Lembaga Perkreditan Desa yang memberikan hak pada pihak kreditor guna melaksanakan pelelangan dalam rangka menjual objek hak tanggungan atas kekuasaan diri sendiri.
\end{abstract}

Kata Kunci: hak eksekutorial; hak tanggungan; lembaga perkreditan desa

\section{Pendahuluan}

Dilihat dari doktrin dari para ahli hukum perihal luasnya subjek yang dicakup serta kaidah dari Ide Hukum yang sangat luas jangkauannya, jika dilihat kembali dalam asal-usul keberadaan Ide Hukum, bisa jadi persoalan berikut adalah dampak yang masuk nalar daripada kapasitas dalam Ide Hukum yang menyambungkan antara Filsafat Hukum yang ciri penjabarannya lebih absurd perihal keseluruhan spekulasi teoritis daripada kajian hukum tersebut, serta Ilmu Hukum Dogmatik yang analisisnya seadanya dalam hukum positif 
pada struktur hukum negara tertentu. (Atmaja, I Dewa Gede dan I Nyoman Putu Budiartha, 2018:3)

Eksistensi kesatuan masyarakat hukum adat di setiap daerah, menjadi ciri khas bangsa Indonesia yang pluralis, terdiri atas masyarakat dengan berbagai macam pondasi sosial beserta desain uniknya sendiri-sendiri yang tersebar di seluruh penjuru daerah yang berada dalam bingkai Negara Kesatuan Republik Indonesia. Keberadaan desa adat di Bali yang memegang teguh kebudayaan dalam setiap aspek pemerintahannya merupakan cerminan dari eksistensi kesatuan masyarakat hukum adat dalam kehidupan masyarakat Bali. peraturan mengenai desa dapat dilihat pada ketentuan UUD RI No. 6/2014 perihal Desa. Yang dimana pengertian desa bisa dilihat pada ketentuan Pasal 1 angka 1 Undang-undang Republik Indonesia Nomor 6 Tahun 2014 tentang Desa Definisi desa berdasarkan KBBI ialah menjadikannya suatu kata nomina (kata benda) yang berdefinisi:

a. sekerumunan rumah yang berada di luar kota yang dimana terdapat kesatuan, kampung, dusun.

b. Udik (dalam arti daerah pedalaman sebagai lawan kota). c. Tempat, tanah, daerah

Wujud tanggung jawab negara dalam desa adat di provinsi Bali ini yang mencerminkan upaya untuk memanifestasikan kedamaian krama atau anggota desanya adalah bersama-sama diciptakannya suatu lembaga yang bernama LPD. Pembentukan lembaga ini adalah realisasi dari semangat konstitusi dalam mewujudkan kesejahteraan umum kepada seluruh lapisan elemen masyarakat Indonesia, yang diserap dan ditujukan kepada warga atau krama desa adat di Bali.

LPD adalah suatu wujud dalam hal lembaga keuangan mikro yang bertempat pada desa adat. LPD ialah suatu BUM yang dimiliki oleh desa adat yang memiliki suatu bidang operasional yang bertujuan menjadikannya sebagai tempat harta benda yang dimiliki oleh desa adat, dimana berwujud uang ataupun suratsurat berharga. LPD dicetuskan dan dilegalkan dari, oleh dan pada masyarakat desa adat semata, dikarenakan pada setiap aturan regulasi dari lembaga ini berpacu pada serta menitik beratkan pada hukum adat itu sendiri yang hidup dan berkembang di setiap wilayah atau wewidangan desa adat setempat. Kapabilitas dan kewenangan LPD dalam menjalankan fungsi intermediasi hanya sebatas terhadap nasabah yang terdiri dari warga atau krama desa adat saja. Dasar pertimbangan kedudukan LPD yang hanya terletak pada batas wilayah desa adat (Putra, Ida Bagus Wyasa, 2011:10)

Lembaga Perkreditan Desa dalam melaksanakan kegiatan perantaraan harus mengacu pada prinsip kehati-hatian, namun tidak dapat dipungkiri, dibalik usaha pemberian pinjaman yang menjanjikan profit margin yang cukup tinggi kepada kreditur, terdapat pula resiko yang berbanding lurus. Resiko yang kerap kali terjadi dalam kegiatan penyaluran kredit oleh LPD adalah wanprestasi dalam bentuk kredit macet. Oleh karenanya, agunan yang boleh didistribusikan oleh debitur pada nilai nan cukup besar hanyalah jaminan yang mempunyai suatu hak yang dinamakan Hak Tanggungan. Pengambilalihan agunan tersebut menimbulkan problematika yang dilematis berkaitan dengan kewenangan dan hak yang bersifat eksekusi oleh Lembaga Perkreditan Desa kepada agunan bercorak Hak Tanggungan atas tanah dimana berkedudukan di luar dari kawasan desa adat dimana lembaga ini tersebut berkedudukan.

Pasal 1 angka 1 UU No. 4/1996 perihal Hak Tanggungan Atas Tanah Beserta BendaBenda yang Berkaitan dengan Tanah adalah suatu hak agunan yang diikatkan dalam hak atas tanah sebagai halnya dijelaskan dalam UU No. 5/1960 perihal Peraturan Dasar Pokok-Pokok Agraria, selanjutnya atau bukan objek-objek lain yang dimana menjadikan saling berkaitan dengan tanah tersebut, guna melunasi piutang terbatas yang melepaskan suatu posisi yang diistimewakan kepada kreditor tertentu kepada kreditor-kreditor lainnya. (H.M. Arba, 2019:207)

Menyinggung maksud dari objek yang bisa dibuatkan agunan piutang dengan Hak Tanggungan, beralaskan pada Pasal 1 angka 1 UUHT, ialah hak atas tanah sebagai halnya dijelaskan pada UU No. 5/1960 perihal Peraturan Dasar Pokok-Pokok Agraria, selanjutnya atau bukan selanjutnya objek-objek lainnya yang dimana menjadikan saling berkaitan dengan tanah tersebut. Dapat dilihat pada Pasal 4 ayat (1) UUHT yang menjabarkan hak-hak atas tanah itu, adalah sebagai berikut:

Hak atas tanah yang dapat dibebani Hak Tanggungan adalah :
a. Hak Milik;
b. Hak Guna Usaha;
c. Hak Guna Bangunan.

Mengenai definisi dari Hak tanggungan sendiri dapat kita lihat dan cermati selaku spesifik pada Peraturan UU No. 4/1996 Perihal 
Hak Tanggungan Atas Tanah beserta Bendabenda yang berkaitan dengan Tanah dapat dilihat dalam Pasal 1 ayat (1). Pembebanan hak atas tanah sebagai agunan hutang selepas hadirnya suatu lembaga yang dinamakan lembaga hak tanggungan oleh sebab itu gunakanlah kelembagaan jaminan hipotik, oleh sebab itu maka waktu itu hak atas tanah ialah merupakan suatu objek hukum pada jaminan hipotik.

berlandaskan pemaparan tersebut, maka penulis berkeinginan guna mengkaji secara mendalam penelitian ini dalam bentuk skripsi dengan judul "Hak Eksekutorial Lembaga Perkreditan Desa Terhadap Benda Jaminan Hak Tanggungan Yang Berkedudukan Di Luar Wilayah Desa Adat"

Berdasarkan pada uraian latar belakang diatas terdapat beberapa rumusan masalah yang penulis angkat, antara lain:

1. Bagaimana Pengaturan Lembaga Perkreditan Desa Sebagai Lembaga Keuangan Desa Adat di Bali ?

2. Bagaimana Eksistensi Lembaga Perkreditan Desa Terhadap Benda Jaminan Hak Tanggungan Yang Berkedudukan di Luar Desa Adat?

\section{Metode}

Metode penelitian pada skripsi berikut adalah normatif dan Jenis pendekatan dalam penelitian skripsi ini terdiri dari strategi Undang -undang serta strategi konseptual. Sumber Bahan Hukum yang dipakai ialah Bahan Hukum Primer berwujud ketentuan Peraturan Perundang-undangan serta Bahan Hukum Sekunder meliputi bentuk tulisan ilmiah tentang hukum. Teknik Pengumpulan Bahan hukum melalui teknik studi dokumentasi dan studi kepustakaan. Analisis Bahan Hukum melalui teknik deskripsi, definisi serta alasan.

\section{Hasil Penelitian Dan Pembahasan}

\section{Pengertian Lembaga Perkreditan Desa (LPD)}

Guna untuk menaikkan kedamaian dalam masyarakat untuk menyerahkan santunan kredit untuk suatu aktivitas bisnis di desa, oleh sebab itu satu diantara yang ada berupa langkah yang memberikan pengutamaan ialah berupa menaikkan suatu aktivitas perkreditan pada desa. Maka dari itu di buatkanlah suatu lembaga yang dinamakan dengan nama Lembaga Perkreditan Desa.

Lembaga Perkreditan Rakyat atau LPD terutama di provinsi Bali adalah suatu tradisi kemasyarakatan guna membantu aktivitas perniagaan pada masyarakat desa adat tempat LPD tersebut berkedudukan. Menjadikannya suatu lembaga perniagaan, keberadaan serta ekspansi lembaga ini di Pulau Dewata beberapa tahun berikut dihadapkan perihal kedudukan rivalitas yang sangat berat dikarenakan terdapat suatu badan perniagaan serupa seperti koperasi, BPR serta bank umum lainnya yang perkembangannya sangat pesat pada saat ini.

LPD adalah suatu lembaga kegiatan perniagaan yang dipunyai oleh desa yang dimana mengimplementasikan suatu aktivitas usahanya pada wilayah lingkungan desa serta krama desa. Kekayaan dari LPD sendiri ialah satu diantara yang ada bersumber pada kekuatan sendiri urunan karma desa. Ketika belum dikonsepkan serta didirikannya lembaga ini di Pulau Dewata ini, masing-masing Desa Adat telah mempunyai sekehe atau paguyuban yang awamnya sekehe ini pula telah mempunyai anggaran ataupun uang kas yang dimana diserahkan kepada sekehe tersebut. (Peters Robinson, 2002:17)

Mengenai legalitas LPD dalam "penggunaan Bidang Usaha" dari Lembaga Perkreditan Desa (LPD) adalah tertuang dalam ketentuan peraturan Perundang-undangan pada Pasal 7 Perda Provinsi Bali No. 3/2017 perihal Lembaga Perkreditan Desa. LPD di Pulau Dewata ini belum bisa dikelompokkan kedalam LKM dikarenakan belum terpenuhinya karakter -karakter dari LKM yang dijelaskan pada UU No. 1/2013 perihal LKM. Bisa dilihat bahwasannya karakter yang utama daripada LKM ialah menjadikannya suatu badan perniagaan. Makna dari dibentuknya LKM ialah guna menyerahkan suatu jasa peningkatan usaha serta memberdayakan krama desa yang dilaksanakan dengan menyerahkan kredit ataupun pembiayaan pada kegiatan usaha berskala kecil maupun besar terhadap masyarakat. lahirnya UU No. 1/2013 perihal LKM yang melepaskan status LPD pada Pasal 39 ayat (3) UUD RI No. 1/2013 Perihal LKM. Pada penjelasan berikut dijelaskan bahwasannya terdapat amanat kepada pemerintah pusat guna memisahkan tentang semua kegiatan yang LPD lakukan dalam perihal pengurusan serta perniagaannya terhadap Desa Adat LPD didirikan, oleh sebab itu bisa dijelaskan bahwasannya kedudukan LPD ialah badan mandiri yang dimiliki Desa Adat. Keadaan tersebut itu juga yang mendasarkan terhadap suatu asas hukum yaitu asas Lex Specialis Derogat Legi Generalis yang berdefinisi aturan hukum yang bercorak khusus tentunya mengesampingkan aturan hukum yang bercorak umum. 


\section{Eksistensi Lembaga Perkreditan Desa Ter- hadap Benda Jaminan Hak Tanggungan Yang Berkedudukan Di Luar Desa Adat}

Lembaga Perkreditan desa ini mempunyai suatu tugas untuk melindungi itikad baik yang sudah diserahkan oleh krama desa menjadi suatu badan penyelenggaraan perniagaan desa adat. ikatan yang diperoleh oleh krama desa bersama LPD diperoleh atas dasar suatu etika yang dinamakan etika itikad baik. Ketika LPD menyerahkan suatu agunan untuk debiturnya akan diselingi dengan kesempatan terjadinya suatu aktivitas kredit macet. Kredit debitur bisa dijeniskan menjadi seperti kredit macet jika menjadikannya satu kedudukan yang mengemuka sesudah diberlangsungkannya berbagai macam langkah guna menanggulangi aktivitas suatu kredit yang problematis akan tetapi apabila nasabah belum pula bisa menyelesaikan suatu tugasnya sebagai halnya dengan yang sudah diagunkan. Oleh karena itu Krama desa yang meminjam dana pada Lembaga Perkreditan Desa berkedudukan menjadi nasabah atau debitur. penyerahan agunan yang dilaksanakan dengan tidak memperhatikan atas dasar kewaspadaan maka bisa menjadi suatu ancaman untuk Lembaga Perkreditan Desa ini sebagai pihak kreditor dan berdampak bagi kesinambungan kegiatan usaha lembaga ini sendiri. Disamping melaksanakan kontrak atau kesepakatan kredit, dibutuhkan adanya suatu agunan yang dibarengi oleh bersamaan dengan pengikatan agunan itu sendiri menjadikannya suatu kualifikasi supaya Lembaga Perkreditan Desa bisa melepaskan pinjamannya tersebut. agunan ialah menjadi suatu hal substansial pada aktivitas pinjam meminjam, oleh sebab itu agunan dapat mempersembahkan suatu kepastian hukum terhadap kreditor bahwasannya utangnya tersebut akan dilunasi oleh pihak debitur. (Suhariningsih, 2011:16)

Jika debitur menggunakan suatu kebendaan berbentuk tanah berupa agunan terhadap kredit yang dilaksanakannya, oleh sebab itu agunan tersebut harus dijaminkan dengan hak yang bernama Hak Tanggungan. Pembebanan hak tanggungan berikut ditujukan supaya pihak kreditur memperoleh satu tanggungan yang mempunyai kekuatan yang bersifat eksekusi atau dinamakan kekuatan eksekutorial, oleh sebab itu tidak menjadikannya suatu persoalan pada saat mengeksekusi agunan tersebut.

Pada definisi kebanyakan Undang-Undang Hak Tanggungan dijelaskan bahwasannya Hak Tanggungan ialah merupakan suatu hak jaminan atas tanah guna untuk melunasi suatu undang tertentu, yang dimana melimpahkan keadaan yang diutamakan untuk kreditor terten- tu kepada kreditor yang lainnya. jadi maksudnya ialah apabila nasabah tersebut wanprestasi, kreditur yang berhak atas Hak Tanggungan tersebut mempunyai hak memindahtangankannya menggunakan pelelangan umum yang dimana tanah yang dijadikan agunan berdasarkan hukum positif yang berlaku, berupa hak melampaui ketimbang kreditor-kreditor yang lainnya. keadaan yang diistimewakan tersebut tentu tidak memangkas jumlah suatu piutangpiutang negara menurut peraturan hukum positif yang berlaku. kehadiran Lembaga Perkreditan Desa di tengah mengambil alih suatu benda agunan yang dibebankan atas hak tanggungan yang terdapat diluar lingkungan desa adat dalam ketentuannya adalah sah, kendatipun ditengah melaksanakan aktivitas usahanya Lembaga Perkreditan Desa semata-mata untuk menyerahkan fasilitas pelayanannya untuk krama desa dimana lokasi lembaga tersebut didirikan. Akan tetapi ditemukan ruang yang diperoleh pada ketentuan Pasal 5 ayat (1) Pergub No. 44/2017 menjadi aturan pelaksanaan Perda No. 3/ 2017 perihal Lembaga Perkreditan Desa.

Ketika belum disahkannya (UU LKM), beralaskan pasal 58 UU No. 7/1992 jo. UU No. 10/1998 perihal Perbankan, Lembaga Perkreditan Desa tersebut diperlukan kedudukan menjadi Bank yang dinamakan BPR, oleh karena itu lembaga ini ditengah kepengurusannya mesti mematuhi semua peraturan yang berlangsung di BPR. Hal berikut serasa belum benar, dikarenakan Lembaga ini memiliki visi serta misi yang bergandengan sangat erat dengan persepsi Tri Hita Karana adalah mengharmonisasikan hubungan antara hubungan manusia dengan Tuhan (parahyangan), mengharmonisasikan hubungan antara manusia dengan manusia (pawongan), dan mengharmonisasikan hubungan antara manusia dengan lingkungan (palemahan). aktivitas penyelenggaraan perniagaan yang diberikan kepada Lembaga Perkreditan Desa dapat dibilang sudah melaksanakan pola manajemen perniagaan terbarukan yang dimana hampir sama dengan metode penyelenggaraan perniagaan sebagaimana mestinya yang dijalankan terhadap lembaga keuangan bank. Ruang lingkup dari aktivitas operasional LPD yang terdiri dari penyerahan utang-piutang serta penampungan keuangan semata- mata dilaksanakan pada batas lingkungan satu desa adat oleh karena itu cuma krama desa adat saja yang bisa memperoleh fasilitas jasa Lembaga Perkreditan Desa tersebut. Akan tetapi memiliki satu pengistimewaan yang melepaskan ruang terhadap lembaga ini guna bisa memberikan kreditnya terhadap krama desa adat yang terdapat di luar batasan ling- 
kungan desa adat melalui satu peraturan yang dimana terdapat hubungan persekutuan antar desa tersebut. Fasilitas yang diberikan Lembaga Perkreditan Desa yang eksklusif hanya bisa diserahkan terhadap krama desa saja oleh sebab itu lembaga ini tentunya berlainan dengan badan perniagaan lainnya.

LKM sendiri bisa menyerahkan fasilitas jasanya terhadap masyarakat pada umumnya, tidak sama dengan LPD yang kurang ditengah menyerahkan fasilitasnya hanya untuk krama desanya saja. Disamping itu, LPD belum bisa melaksanakan aktivitas yang sama dengan apa yang dilaksanakan terhadap LKM. Aspek-aspek itulah yang menjadikan LPD tidak masuk dalam golongan menjadi LKM. UU LKM memberikan kedudukan LPD menjadi suatu badan keuangan yang mempunyai kedudukan yang diistimewakan, yang dimana dapat ditemukan dalam ketentuan Pasal 39 ayat (3) UU No.1/2013 Perihal LKM Jadi aturan mengenai kemunculan LPD yang menjadikannya bagian dari semangat bermasyarakat krama desa adat di Pulau Dewata ini harus bertekuk lutut kepada hukum adat tempat LPD tersebut didirikan sebagai halnya yang sudah disahkan dalam peraturan perundang-undangan yang dapat dilihat pada Pasal 39 ayat (3) UU LKM.

\section{Simpulan}

Peraturan mengenai LPD tertuang pada PerDa Provinsi Bali No. 3/2017 Perihal Lembaga Perkreditan Desa. Lembaga tersebut menjadikannya badan perniagaan desa adat yang mempunyai posisi yang diistimewakan oleh UU LKM sesuai ketentuan pasal 39 ayat (3) UU LKM. lahirnya LKM utamanya ialah LPD bahwasanya LPD dalam pembangunannya menuruti semua ketentuan yang telah diatur terhadap desa adat tiap-tiap lokasi desa LPD tersebut berdiri.

Mengenai Eksistensi kekuatan eksekutorial LPD ketika mengakuisisi objek tetap menjadi benda agunan nan diikatkan Hak Tanggungan yang terdapat dibatas lokasi desa adat dalam kenyataan adalah benar sesuai ketentuan Pasal 5 ayat (1) Pergub No. 44/2017. Kemudian UU No. 4/1996 perihal Hak Tanggungan Atas Tanah Beserta Benda-Benda Yang Berkaitan Dengan Tanah, menjadikannya mempunyai hak pada kreditor yang memiliki Hak Tanggungan guna melangsungkan pelelangan dalam rangka melego benda Hak Tanggungan terhadap kekuasaannya sendiri selanjutnya memakai akibat lelang berikut menjadi lunasnya hutang si debitur.

\section{Daftar Pustaka}

Arba, H. M. (2019). Hukum A graria Indonesia. Cet.6. Jakarta: Sinar Grafika.

Atmaja, I, D, G., Budiartha, I, N, P. (2018). Teori-Teori Hukum. Malang: Setara Press.

Robinson, P. (2002) Lembaga Perkreditan Desa Di Bali, Proyek Pemerintah Indonesia Dengan Bantuan USAID. Jakarta: Financial Institution Developments Project.

Suhariningsih. (2011). Analisis Yuridis Terhadap Perjanjian Kredit Dengan Jaminan "Barang Inventory" Dalam Bingkai Jaminan Fidusia, Malang: Press Malang.

Wyasa, I, B, P. (2011). Landasan Teoritik Pengaturan LPD Sebagai Lembaga Keuangan Komunitas Masyarakat Hukum Adat di Bali. Denpasar: Udayana University Press. 